\title{
Pelatihan Pengolahan Nilai Dan Analisis Butir Soal Dan Hasil Belajar Berbasis Ms. Office Excel di SMP Islam Al-Azhar NW Kayangan
}

\author{
Dahlia Rosma Indah, Hendrawani, Yusran Khery, Suryati, Husnul Hatimah \\ Dosen IKIP Mataram \\ dahliarosmaindah@,ikipmataram.ac.id
}

\begin{abstract}
Abstrak; Melakukan pengelolaan nilai, analisis butir soal dan hasil belajar siswa merupakan kewajiban setiap guru. Dengan begitu, guru akan dapat melakukan diagnosa masalah dalam pembelajaran, menyimpulkan tingkat ketercapaian tujuan pembelajaran, dan memutuskan program tindak lanjut. Permasalahan yang ada di SMP Islam Al-Azhar NW Kayangan adalah, hanya sebagian kecil guru yang melakukan analisis butir soal dan hasil belajar siswa yang dibuktikan dengan dokumen analisis hasil belajar yang ada. Hal tersebut disebabkan oleh sebagian besar guru menganggap anlisis butir soal dan hasil belajar sebagai kegiatan yang rumit dan memeerlukan waktu yang sangat banyak. Hampir semua guru tidak menguasai program yang dapat digunakan untuk mengolah data angka. Masalah ini dapat diatasi jika guru memiliki kemampuan mengoperasikan program Ms. Office Excel sehingga proses pengolahan nilai, anlaisis butir soal dan hasil belajar dapat dilakukan dengan lebih efisien. Kegiatan telah terselenggara dengan baik. Respon peserta kegiatan sangat baik dengan skor rata-rata penilaian total yakni 82.5.
\end{abstract}

Kata Kunci:

\section{PENDAHULUAN}

Salah satu peran guru adalah sebagai evaluator yang melakukan evaluasi dalam periode tertentu dan mengadakan penilaian terhadap hasil yang telah dicapai. Dengan demikian guru dapat mengetahui keberhasilan pencapaian tujuan, penguasaan siswa terhadap pelajaran, ketepatan dan keefektifan metode mengajar yang digunakan. Dengan penilaian, guru dapat mengetahui prestasi yang dicapai siswa setelah proses belajar. Informasi yang diperoleh melalui evaluasi ini merupakan umpan balik terhadap proses belajar mengajar. Dengan begitu guru dapat membantu siswa untuk bisa berhasil dalam belajarnya (Usman, 2013).

Seorang guru harus mampu melakukan analisis dari kegiatan penilian yang dilakukannya. Melalui analisis guru akan mendapatkan umpan balik yang tepat sehingga bisa memberikan keputusan yang tepat ke arah pengembangan kurikulum disamping sebagai unsur penunjang administrasi guru (Hamalik, 2009).

Sudah ada aplikasi yang dapat digunakan guru untuk melakukan analisis tes dan hasil belajar, seperti Anabut, Anatest, dan Program Raport yang ketiga-tiganya merupakan aplikasi berbasis Ms. Office
Excel. Program-program ini memang menawarkan kemudahan, namun tidak dapat dimodifikasi sesuai kebutuhan guru. Guru yang tidak memiliki pengetahuan dasar Ms. Office Excel mengalami kesulitan mengoperasikan program ini. Program anabut dan anatest merupakan program yang cukup memadai, kesulitan yang ditemukan guru adalah ketika mereka harus menggabungkan analisis dari beberapa penilaian. Program raport digunakan guru untuk menyusun laporan hasil belajar siswa. Salah satu masalah yang kami temukan bahwa guru adalah tidak mampu memodifikasi kolom dalam program tersebut sehingga sesuai kebutuhan. Masalah inilah yang ditemukan di SMP Islam Al-Azhar NW Kayangan.

Masalah tersebut dapat diatasi jika guru-guru di SMP Islam Al-Azhar NW Kayangan memiliki keterampilan dasar Ms. Office Excel. Maka diperlukan suatu kegiatan pelatihan penggunaan program Ms. Office Excel untuk pengolahan nilai, analisis butir soal dan hasil belajar untuk guru di SMP Islam Al-Azhar NW Kayangan.

\section{TARGET DAN LUARAN}

\section{A. Target Program}

Program PPM ini memiliki target sebagai berikut: 
1. Program ini akan diperuntukkan bagi guru di SMP Islam Al-Azhar NW Kayangan.

2. Memberi pelatihan dan pengalaman belajar bagi guru tentang pengelolaan nilai, analisis butir soal dan hasil belajar kepada guru-guru SMP Islam Al-Azhar NW Kayangan.

3. Memberi contoh nyata kepada guru dan membentuk kesadaran guru untuk memanfaatkan teknologi computer dan informasi sehingga tugas guru bisa dilakukan dengan efisien.

\section{B. Luaran Program}

Kegiatan ini dapat menghasilkan peningkatan pengetahuan dan keterampilan guru dalam melakukan analisis butir soal dan hasil belajar.

\section{METODE PELAKSANAAN}

\section{A. Mekanisme Pelaksanaan Kegiatan PPM}

a) Melakukan survey lokasi dan sosialisasi kegiatan PPM kepada pihak sekolah.

b) Melakukan pelatihan pengelolaan nilai, analisis butir soal dan hasil belajar menggunakan Ms. Office Excel.

\section{B. Rencana Keberlanjutan Program}

Program PPM ini akan berlanjut dengan kegiatan hubungan silaturahmi yang berkelanjutan dengan pihak sekolah dan tim PPM bisa memberi pendampingan .

\section{HASIL}

Kegiatan ini dilaksanakan melalui presentasi/seminar dan diskusi. Materi seminar disampaikan oleh tim dosen. Setelah penyampaian materi, dilanjutkan dengan diskusi antara pemateri dan peserta. Dalam kegiatan tersebut, peserta diminta untuk mengisi angket respon terhadap kegiatan ini. Ringkasan respon peserta tersaji dalam gambar 4.1.

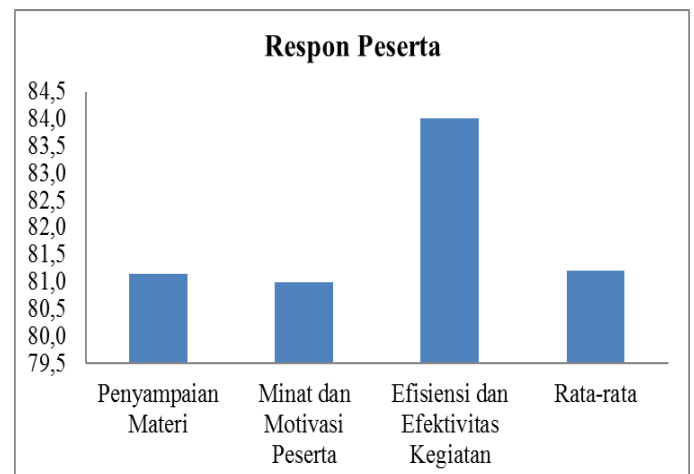

Gambar 4.1. Ringkasan Respon Peserta Kegiatan

Angket respon peserta terdiri dari bebrapa item pernyataan yakni 7 item pernyataan mengenai penyampaian materi, 2 item mengenai minat dan motivasi peserta, dan 4 item mengenai efisiensi dan efektifitas kegiatan. Angket diberikan kepada peserta. Ringkasan data dalam gambar 5.1 merupakan nilai rata-rata respon pada item serumpun dari seluruh peserta pengisi angket. Penilaian peserta pada pada skor skala 1-5 (sangat buruk, buruk, cukup, baik, dan sangat baik) diubah menjadi skala skor 0-100. Data respon peserta menunjukkan bahwa penyampaian materi telah dilakukan dengan sangat baik dan menarik $(82,5)$. Diskusi dan tanya jawab antara pemateri dan peserta menyebabkan minat dan motivasi peserta menjadi sangat baik $(81,0)$. Pengemasan kegiatan yang baik menyebabkan kegiatan dapat berjalan dengan efektif dan efisien $(84,0)$. Secara keseluruhan kegiatan telah dilaksanakan dan memperoleh respon dengan sangat baik $(82,5)$.

Selain mengisi angket respon, peserta juga diminta untuk mengisi kolom komentar. Komentar dari beberapa orang peserta tersaji dalam tabel 4.1.

Tabel 4.1. Respon dan Komentar Beberapa Peserta Kegiatan

\begin{tabular}{|l|l|l|l|}
\hline No. & Respon & Kategori & \multicolumn{1}{c|}{ Komentar } \\
\hline 1 & 76 & Baik & $\begin{array}{l}\text { Mari kita tingkatkan minat untuk belajar dengan } \\
\text { sebaik mungkin }\end{array}$ \\
\hline 2 & 84 & $\begin{array}{l}\text { sangat } \\
\text { baik }\end{array}$ & $\begin{array}{l}\text { Kegiatan ini sangat memberikan manfaat bagi saya } \\
\text { pribadi dan guru pada umumnya dan ini bisa } \\
\text { dijadikan sebagai bentuk model pembelajaran yang } \\
\text { sangat menarik, efisien dan efektif di lemabaga } \\
\text { kami }\end{array}$ \\
\hline 3 & 70 & baik & Penyampaian isi materi oleh tutor cukup baik \\
\hline 4 & 86 & $\begin{array}{l}\text { sangat } \\
\text { baik }\end{array}$ & $\begin{array}{l}\text { Workshop ini sangat bermanfaat terutama bagi kami } \\
\text { guru-guru memudahkan dalam membuat materi } \\
\text { agar menarik minat siswa untuk belajar dan } \\
\text { memperhatikan terutama mapel matematika }\end{array}$ \\
\hline 5 & 74 & baik & $\begin{array}{l}\text { Kegiatan ini sangat bermanfaat untuk kita semua } \\
\text { terutama untuk saya pribadi karena bisa menambah } \\
\text { pengetahuan dan wawasan saya }\end{array}$ \\
\hline 6 & 90 & $\begin{array}{l}\text { sangat } \\
\text { baik }\end{array}$ & $\begin{array}{l}\text { Kegiatan kegiatan seperti ini sangat positif semoga } \\
\text { ini bukan yang pertama dan terakhir }\end{array}$ \\
\hline 7 & 88 & $\begin{array}{l}\text { sangat } \\
\text { baik }\end{array}$ & $\begin{array}{l}\text { Perlu lebih banyak diskusi agar materi lebih jelas, } \\
\text { perjelas langkah-langkah dalam pembuatan bahan } \\
\text { ajar }\end{array}$ \\
\hline
\end{tabular}




\section{KESIMPULAN}

Kegiatan pengabdian pada masyarakat telah dilaksanakan dengan lancar. Respon peserta kegiatan sangat baik dengan skor ratarata penilaian total yakni 82.5 .

\section{DAFTAR PUSTAKA}

Andrizon. 2013. Tutorial Flash pembuatan media interaktif. UNY: Laboratorium Komputer.

Badi, H. J. Zeki, A.M. Faris, W. F. Othman, R. B. 2013. Animation as a Problem Solving Technique in Mechanical Engineering Education.International Jurnal of Scientific \& Engineering Reseach.Vol. 4.No. 5.ISSN 2229-5518.

Dewi, Citra Ayu \& Ahmadi.2014. Pengaruh Pembelajaran SAVI Berbasis Media Simulasi Interaktif Terhadap Keterampilan Berpikir Kritis dan Pemahaman Konsep Mahasiswa Pada Materi Elektrokimia. Jurnal Prisma Sains. Vol. 2 No.1. ISSN 2338-4530.

Dinas Pendidikan, Olahraga dan Kebudayaan. 2015. Jumlah Sekolah SMA dan kelas.Kabupaten Lombok Barat.

Meyer, David E \& Sargent, Andrew L. 2007.An interactive computer program to help students learn molecular symmetry elements and operations.Journal of chemical education, 84(9): 1551.

Waryanto, Nur Hadi. 2009. Teknik Pembuatan Media Pembelajaran Interaktif dengan Macromedia Flash. UNY: FPMIPA. 